\title{
SYNTHESIS AND RADIOPROTECTIVE PROPERTIES OF NEW METALLATHIAZOLIDINES, DIALKYLOXATHIAGERMOLANES, DIALKYLGERMOCANES AND METALLADITHIOACETALS
}

\author{
Ghassoub Rima1, Jacques Satge ${ }^{1}$, Henri Sentenac-Roumanou2, Marc Fatome ${ }^{3}$, \\ Jean-Denis Laval ${ }^{3}$, Claude Lion ${ }^{4}$, Christian Thiriot ${ }^{2}$, Rodolphe Dagiral ${ }^{1}$ and Christine Martin ${ }^{3}$ \\ ${ }^{1}$ Laboratoire d'Hétérochimie Fondamentale et Appliquée, UPRES-A 5069 du CNRS \\ Université Paul Sabatier, 118 route de Narbonne, F-31062 Toulouse Cedex, France \\ 2 Direction des Recherches et Etudes Techniques, 26 Bd Victor, F-00460 Armées, France \\ 3 Unité de Radioprotection, Centre de Recherches du Service de Santé des Armées, \\ 24 avenue des Maquis du Grésivaudan, F-38702 La Tronche Cedex, France \\ 4 Institut de Topologie et de Dynamique des Systémes de l' Université de Paris VII, \\ Associe au CNRS, 1 rue Guy de la Brosse, F-75005 Paris, France
}

\begin{abstract}
New organogermanium and organosilicon compounds have been synthesized and their pharmacological properties (toxicity, radioprotective activity) have been studied. A notable decrease in the toxicity and a rather large increase in the radioprotective activity of these new derivatives are noted in comparison with the starting organic compounds.
\end{abstract}

\section{Introduction}

We have realized a considerable work in the field of the pharmacological activity and chemical radioprotection of organogermanium and organosilicon compounds. In these investigations we have developped the synthesis and study of the biological activity of some organometallic compounds such as metallathiazolidines and metalladithioacetals of cysteamine, $\mathrm{N}$ substituted cysteamine, methylcysteamine, $\mathrm{N}$-(2-thioethyl)-1,3-diaminopropane and naphthylmethylimidazoline.

All these derivatives have been tested in the field of radioprotection and they have shown a lower toxicity and led to a dose reduction factor (DRF) with values in the range of 1.4 and 1.75 $[1-9]$.

We report in this paper the synthesis, toxicity and radioprotective activity of some new silaand germathiazolidines, dialkyloxathiagermolanes, dialkyldithiagermocanes, sila- and germadithioacetals.

\section{Sila- and germathiazolidines}

$$
\begin{aligned}
& \mathrm{M}=\mathrm{Si} ; \mathrm{R}_{1}=\mathrm{R}_{2}=-\mathrm{SCH}_{2} \mathrm{CH}_{2} \mathrm{NH}_{2} \cdot \mathrm{HCl}, \mathrm{R}_{3}=-\left(\mathrm{CH}_{2}\right)-\mathrm{R}_{3} \mathrm{R}_{2} \mathrm{M}_{3} \\
& \mathrm{M}=\mathrm{Ge} ; \mathrm{R}_{3}=-\mathrm{CH}_{2} \mathrm{CH}_{2} \mathrm{CNH}_{2} \\
& \mathrm{R}_{1}=\mathrm{R}_{2}=\mathrm{i}-\mathrm{C}_{5} \mathrm{H}_{11} \quad 2 \\
& \mathrm{R}_{1}=\mathrm{R}_{2}=\mathrm{n}_{-} \mathrm{C}_{6} \mathrm{H}_{13} \quad 3 \\
& \mathrm{R}_{1}=\mathrm{p}-\mathrm{CH}_{3} \mathrm{C}_{6} \mathrm{H}_{4}, \mathrm{R}_{2}=\mathrm{CH}_{3} \quad 4
\end{aligned}
$$




\section{Dialkyloxathiagermolanes}<smiles>[R20][GeH2]Oc1cccnc1</smiles>

$$
\begin{array}{ll}
R=n-\mathrm{C}_{6} \mathrm{H}_{13} & \mathbf{5} \\
\mathrm{R}=-\mathrm{SCH}_{2} \mathrm{CH}_{2} \mathrm{NH}_{2} \cdot \mathrm{HCl} & \mathbf{6}
\end{array}
$$

\section{Dialkyldithiagermocanes}

$$
\begin{aligned}
& \mathrm{R}_{2} \mathrm{Ge}\left(\mathrm{SCH}_{2} \mathrm{CH}_{2}\right)_{2} X \\
& X=\mathrm{S}, \mathrm{R}=\mathrm{r}-\mathrm{C}_{5} \mathrm{H}_{11} \quad 7, R=n-\mathrm{C}_{6} \mathrm{H}_{13} \quad 9 \\
& X=\mathrm{O}, \mathrm{R}=\mathrm{i}-\mathrm{C}_{5} \mathrm{H}_{11} \quad 8, R=n-C_{6} \mathrm{H}_{13} \quad 10
\end{aligned}
$$

\section{Sila- and germadithioacetals}

$$
\begin{aligned}
& \mathrm{R}_{1} \mathrm{R}_{2} \mathrm{M}\left[\mathrm{SCH}_{2} \mathrm{CH}_{2} \mathrm{NHR}_{3}\right]_{2} \\
& \mathrm{M}=\mathrm{Si} ; \mathrm{R}_{3}=-\left(\mathrm{CH}_{2}\right)_{3}=\mathrm{R}_{2}=-\mathrm{SCH}_{2} \mathrm{CH}_{2} \mathrm{NH}_{2} \cdot \mathrm{HCl} 11 \\
& \mathrm{M}=\mathrm{Ge} ; \mathrm{R}_{3}=-\mathrm{CH}_{2} \mathrm{CH}_{2} \mathrm{CNH}_{2} \\
& \mathrm{R}_{1}=\mathrm{R}_{2}=\mathrm{i}-\mathrm{C}_{5} \mathrm{H}_{11} \\
& \mathrm{R}_{1}=\mathrm{R}_{2}=\mathrm{n}-\mathrm{C}_{6} \mathrm{H}_{13} \\
& \mathrm{R}_{1}=\mathrm{p}-\mathrm{CH}_{3} \mathrm{C}_{6} \mathrm{H}_{4}, \mathrm{R}_{2}=\mathrm{CH}_{3}
\end{aligned}
$$

2,2'-thiodiethanethiol (Sigma-Aldrich Chimie)

$\mathrm{HSCH}_{2} \mathrm{CH}_{2} \mathrm{SCH}_{2} \mathrm{CH}_{2} \mathrm{SH} \quad 15$

2,2'-oxydiethanethiol (Sigma-Aldrich Chimie)

$\mathrm{HSCH}_{2} \mathrm{CH}_{2} \mathrm{OCH}_{2} \mathrm{CH}_{2} \mathrm{SH} \quad 16$

3-[N-(2-mercaptoethyl)]aminopropanamide WR-2529 [10]

$$
\mathrm{HSCH}_{2} \mathrm{CH}_{2} \mathrm{NHCH}_{2} \mathrm{CH}_{2} \mathrm{CNH}_{2} \quad 17
$$




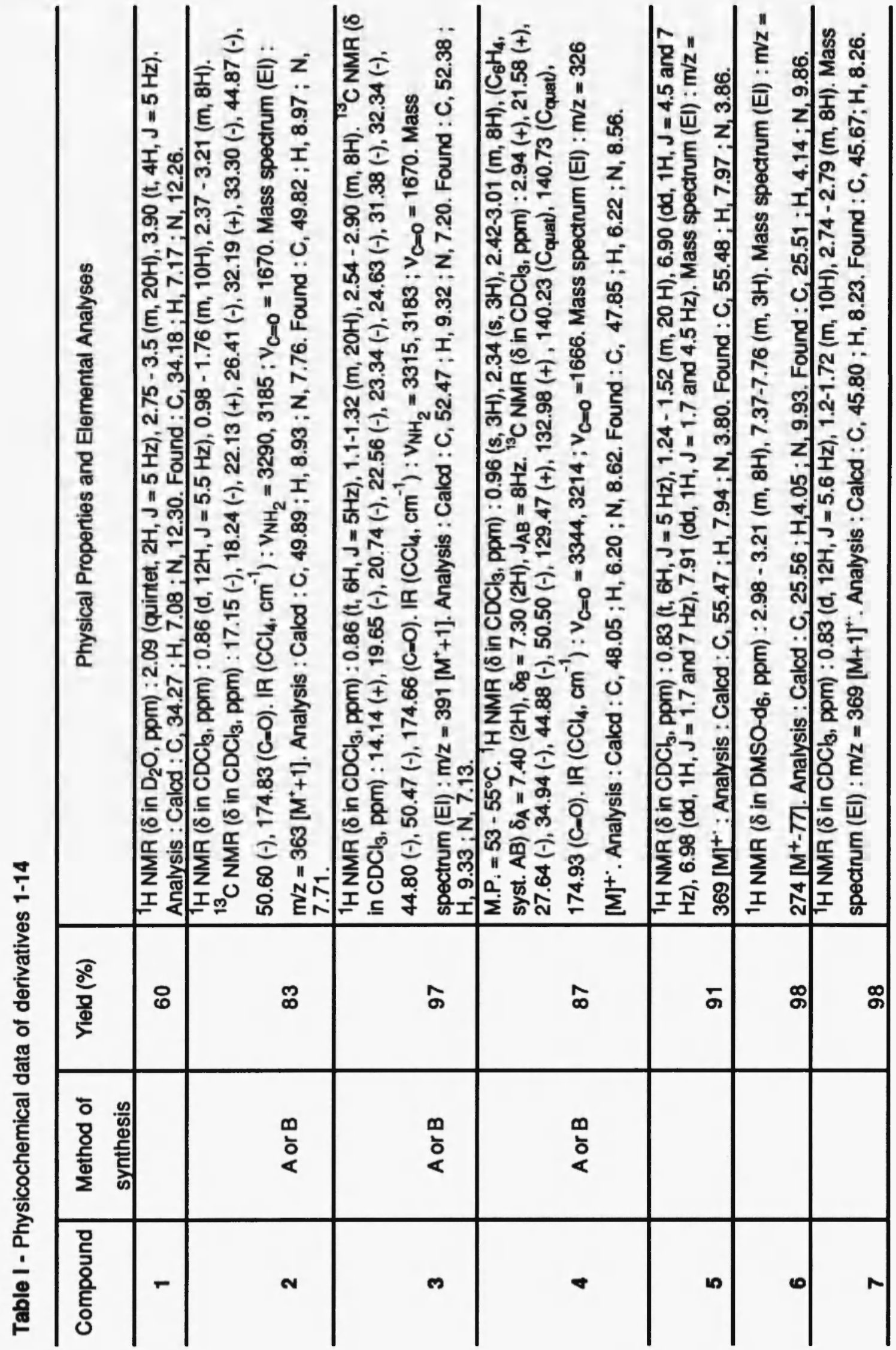




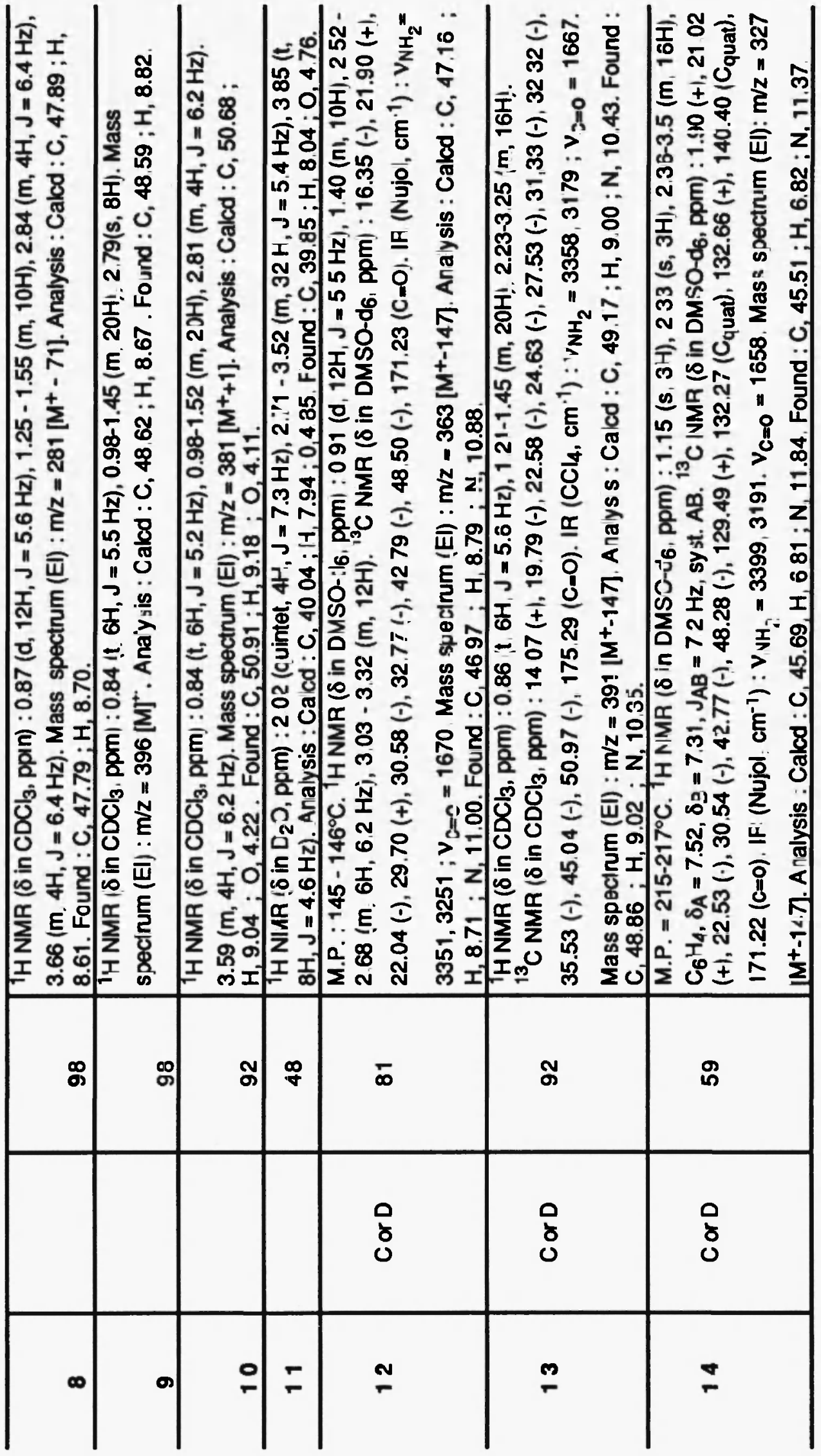




\section{Materials and methods}

All manipulations were carried out under dry nitrogen or argon. Solvents were freshly distilled from sodium/benzophenone before use. IR spectra were recorded on a Perkin-EImer 1600FT-IR spectrophotometer. ${ }^{1} \mathrm{H}$ NMR and ${ }^{13} \mathrm{C}$ NMR spectra were recorded on a Bruker $80 \mathrm{MHz}$ and AC-200 spectrometer ; the multiplicity of the ${ }^{13} \mathrm{C}$ NMR signals was determined by the APT technique and quoted as (+) for $\mathrm{CH}_{3}$ and $\mathrm{CH}$, and $(-)$ for $\mathrm{CH}_{2}$ and $\mathrm{C}_{\text {quat }}$ for quaternary carbon atoms. Mass spectra under electron impact (EI) conditions at $70 \mathrm{eV}$ and $10 \mathrm{eV}$ were recorded on a Hewlett-Packard 5989 and Nermag R10-10H spectrometers. Melting points were taken on a hotplate microscope apparatus Leitz Biomed. Elemental analyses $(C, H, N, O)$ were performed at the Laboratoire de Microanalyse de l'Ecole Nationale Supérieure de Chimie de Toulouse.

\section{Silathiazolidine 1}

To a suspension of $\left(\mathrm{HCl} . \mathrm{H}_{2} \mathrm{NCH}_{2} \mathrm{CH}_{2} \mathrm{~S}\right)_{2} \mathrm{SiCl}_{2}$ [4] $(5 \mathrm{~g}, 15.42 \mathrm{mmol})$ in tetrahydrofuran $(100 \mathrm{ml})$ was added dropwise with stirring $(3.15 \mathrm{~g}, 15.42 \mathrm{mmol})$ of 4-[(2-thioethyl)-3aminopropyl]morpholine [9] in $70 \mathrm{ml}$ of anhydrous tetrahydrofuran. The resulting reaction mixture was refluxed for $3 \mathrm{~h}$, followed by cooling to room temperature and filtration. The precipitate was washed twice with anhydrous pentane $(50 \mathrm{ml})$ and then dried in vacuo. A white solid, compound 1 $(4.22 \mathrm{~g}, 60 \%)$ was collected.

\section{Syntheses of germathiazolidines 2-4}

These compounds were prepared by two methods : A and B<smiles>NC(=O)CCN1CCS[Ge]1(c1ccccc1)c1ccccc1</smiles>

Method A

Di(isoamyl)dichlorogermane $(3.96 \mathrm{~g}, 13.86 \mathrm{mmol})$ in THF $(70 \mathrm{ml})$ was added to $\mathrm{HSCH}_{2} \mathrm{CH}_{2} \mathrm{NHCH}_{2} \mathrm{CH}_{2} \mathrm{C}(\mathrm{O}) \mathrm{NH}_{2}(2.05 \mathrm{~g}, 13.85 \mathrm{mmol})$ and triethylamine $(3.08 \mathrm{~g}, 30.50 \mathrm{mmol})$ in THF $(100 \mathrm{ml})$. The mixture was refluxed for $2 \mathrm{~h}$ with stirring. After filtration to remove the precipitate $\mathrm{Et}_{3} \mathrm{~N} . \mathrm{HCl}$, the filtrate concentrated under reduced pressure, afforded a white pasty product 2 $(4.16 \mathrm{~g}, 83 \%)$.

Method B

Bis(diethylamino)diisoamylgermane $(4 \mathrm{~g}, 11.15 \mathrm{mmol}$ ) was added dropwise to a stirring mixture of $\mathrm{HSCH}_{2} \mathrm{CH}_{2} \mathrm{NHCH}_{2} \mathrm{CH}_{2} \mathrm{C}(\mathrm{O}) \mathrm{NH}_{2}(1.65 \mathrm{~g}, 11.15 \mathrm{mmol})$ in anhydrous THF (100 ml). The mixture was refluxed under argon for $3 \mathrm{~h}$ with stirring. The solution was concentrared in vacuo to afford the compound 2 (3.42 g, $85 \%)$.

\section{2,2-di-n-hexyl-4,5-pyridino-1,3,2-oxathiagermolane}

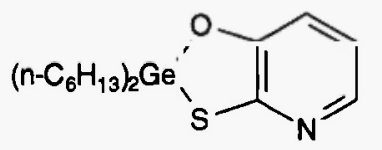

Di-n-hexyldichlorogermane $(5.97 \mathrm{~g}, 19.03 \mathrm{mmol})$ in $20 \mathrm{ml}$ of THF was added dropwise to a stirring solution of 2-mercapto-3-pyridinol $(2.42 \mathrm{~g}, 19.03 \mathrm{mmol})$ and freshly distilled triethylamine $(4.24 \mathrm{~g}, 42.86 \mathrm{mmol})$ in THF $(100 \mathrm{ml})$. The mixture was refluxed for $2 \mathrm{~h}$ with stirring. After the mixture had cooled to room temperature it was filtered under argon to remove the precipitate $\mathrm{Et}_{3} \mathrm{~N}$. $\mathrm{HCl}$. Removal of volatiles (under reduced pressure) from the filtrate, afforded a yellow liquid product 5 (6.36 g, $91 \%)$.

\section{2,2-(2-thioethylaminohydrochloride)-4,5-pyridino-1,3,2-oxathiagermolane}<smiles>CCCCCCCCO</smiles> 

Metalladithioacetals

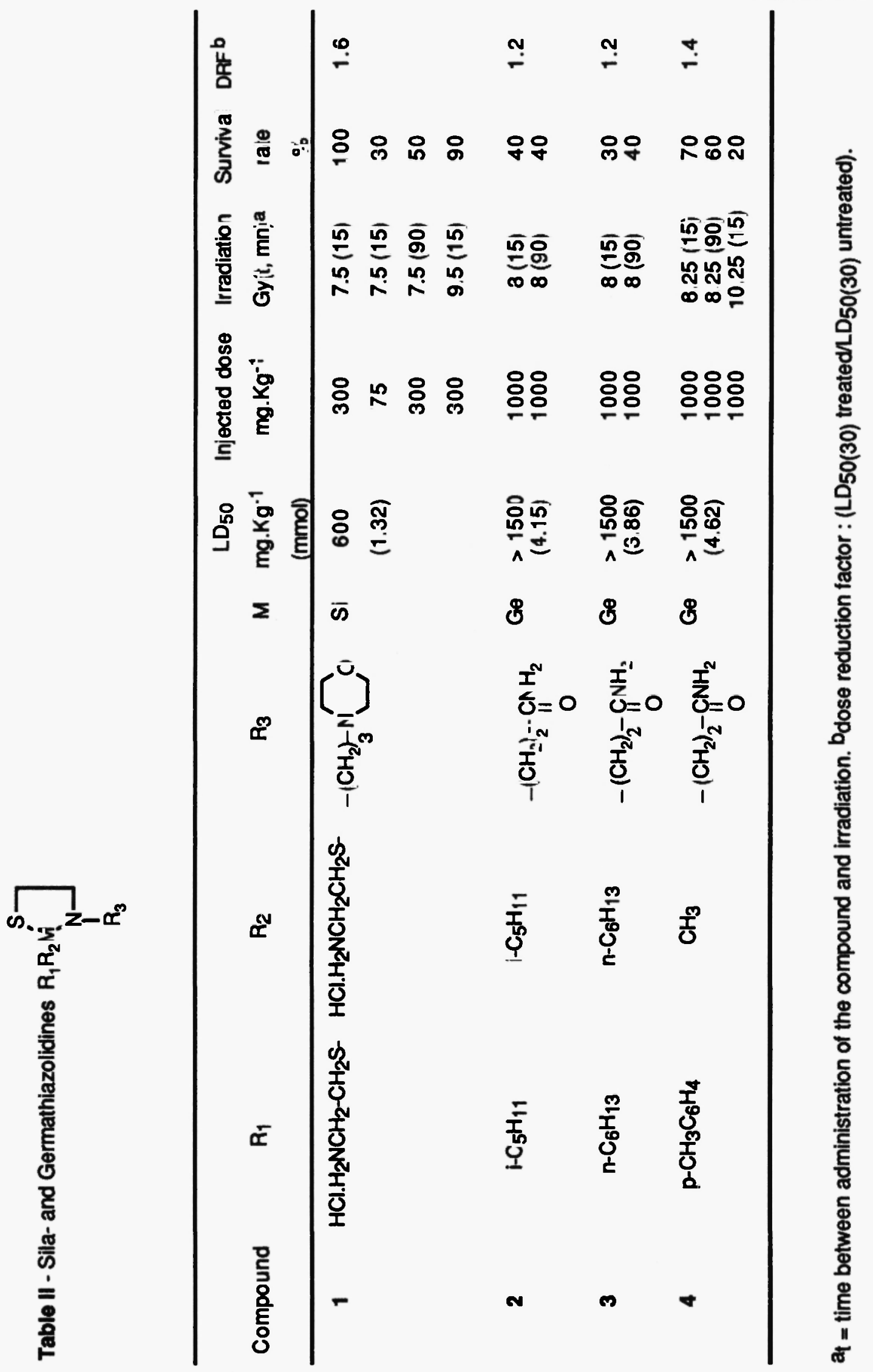


2-mercapto-3-pyridinol $(0.5 \mathrm{~g}, 3.93 \mathrm{mmol})$ in THF $(50 \mathrm{ml})$ was added dropwise to a stirring suspension of bis(2-thioethylaminohydrochloride)dichlorogermanium $(1.45 \mathrm{~g}, 3.93 \mathrm{mmol})$ in $50 \mathrm{ml}$ of THF. The mixture was refluxed for $2 \mathrm{~h}$ with stirring. After which the time the mixture was filtered and the yellow precipitates of 6 were collected $(1.63 \mathrm{~g}, 98 \%)$, washed with pentane, and dried in vacuo .

\section{Dialkylgermocanes}

\section{2,2-di-isoamyl-6-thia-1,3,2-dithiagermocane}

$$
\left(\mathrm{i}-\mathrm{C}_{5} \mathrm{H}_{11}\right)_{2} \mathrm{Ge}\left(\mathrm{SCH}_{2} \mathrm{CH}_{2}\right)_{2} \mathrm{~S} \quad 7
$$

To a solution of $2,2^{\prime}$-thiodiethanethiol $(4.09 \mathrm{~g}, 26.50 \mathrm{mmol})$ and triethylamine $(5.9 \mathrm{~g}, 58.31$ $\mathrm{mmol}$ ) in $100 \mathrm{ml}$ anhydrous tetrahydrofuran was added, dropwise with stirring, diisoamyldichlorogermane $(7.57 \mathrm{~g}, 26.50 \mathrm{mmol})$ in $70 \mathrm{ml}$ of THF. A white precipitate was gradually formed. The mixture was refluxed for $2 \mathrm{~h}$ with stirring. Filtration, followed by removal of the solvents in vacuo gave a quantitative yield of 7 .

Compounds 8-10 were prepared analogously from the appropriate dichlorogermane and diethanethiol $X\left(\mathrm{CH}_{2} \mathrm{CH}_{2} \mathrm{SH}\right)_{2}(\mathrm{X}=\mathrm{O}, \mathrm{S})$.

\section{Siladithioacetal}

$$
\left(\mathrm{HCl} . \mathrm{H}_{2} \mathrm{NCH}_{2} \mathrm{CH}_{2} \mathrm{~S}\right)_{2} \mathrm{Si}\left[\mathrm{SCH}_{2} \mathrm{CH}_{2} \mathrm{NH}\left(\mathrm{CH}_{2}\right)_{3} \mathrm{~N}^{\prime} \mathrm{O}\right]_{2}
$$

4-[(2-thioethyl)-3-aminopropyl]morpholine $(5.04 \mathrm{~g}, 24.68 \mathrm{mmol})$ in THF $(70 \mathrm{ml})$ was added dropwise to a stirring suspension of $\left(\mathrm{HCl} . \mathrm{H}_{2} \mathrm{NCH}_{2} \mathrm{CH}_{2} \mathrm{~S}_{2}\right)_{2} \mathrm{SiCl}_{2}(4.00 \mathrm{~g}, 12.34 \mathrm{mmol})$ in THF (100 $\mathrm{ml}$ ). The mixture was refluxed for $3 \mathrm{~h}$ with stirring. The white precipitate was filtered, washed twice with pentane $(50 \mathrm{ml})$, and dried in vacuo. A white solid, compound $11(3.9 \mathrm{~g}, 48 \%)$ was collected.

\section{Germadithioacetals}

These compounds were also synthesized by two methods : $C$ and $D$

Method C

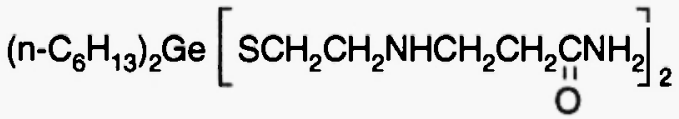

To a stirred mixture of 3-[N-(2-mercaptoethyl)]aminopropanamide $(2.76 \mathrm{~g}, 18.61 \mathrm{mmol})$, triethylamine $(2.07 \mathrm{~g}, 20.47 \mathrm{mmol})$ and $150 \mathrm{ml}$ of THF a solution of dichlorodihexylgermane $(2.92 \mathrm{~g}$, $9.30 \mathrm{mmol}$ ) in $50 \mathrm{ml}$ of THF was added slowly. The reaction mixture was refluxed for $2 \mathrm{~h}$, filtered at ambient temperature under argon, concentrated in vacuo to afford the compound $13(4.6 \mathrm{~g}, 92 \%)$.

Method D

To a stirred mixture of 3-[N-(2-mercaptoethyl)]aminopropanamide $(2.76 \mathrm{~g}, 18.61 \mathrm{mmol})$ in $100 \mathrm{ml}$ of THF was added, dropwise with stirring bis(diethylamino)dihexylgermane (3.6 g, 9.31 $\mathrm{mmol}$ ) in $\mathbf{5 0 ~ m l}$ of THF. The mixture was refluxed for $2 \mathrm{~h}$. Removals of volatiles (under reduced pressure) to afford compound 13.

Physicochemical data of derivatives 1-14 synthesized in this paper are reported in Table I.

\section{Pharmacology : evaluation of radioprotection}

Male CD1 mice (Charles River, France), $25 \mathrm{~g}$ body weight, were used. Compounds were injected intraperitoneally 15 of 90 min before irradiation. The irradiation dose was $L D_{100} / 30$, days for untreated control mice $(7.5,8$ or $8.25 \mathrm{~Gy}$, according to the irradiation date) or a 2 Gy greater dose. The injected dose of compound was equal to either one-half or one-eighth of the $L_{50}$ value which had been determined previously. The radioprotective effect was evaluated by the dose reduction factor (DRF), which is the ratio between the $\mathrm{LD}_{50} / 30$ days of treated mice and that of control mice (between 6.5 and $7.25 \mathrm{~Gy}$, according to the date).

Irradiation was applied using a cobalt-60 source at a dose rate of $0.3-0.4$ Gy $\min ^{-1}$ according to the date. During irradiation, animals were placed in a Plexiglass box with 30 cells in a homogeneous field $28.5 \mathrm{~cm} \times 28.5 \mathrm{~cm}$ in area. Dosimetry was checked with an ionization chamber dosimeter. The different $L_{50}$ values were determined by probit analysis. 

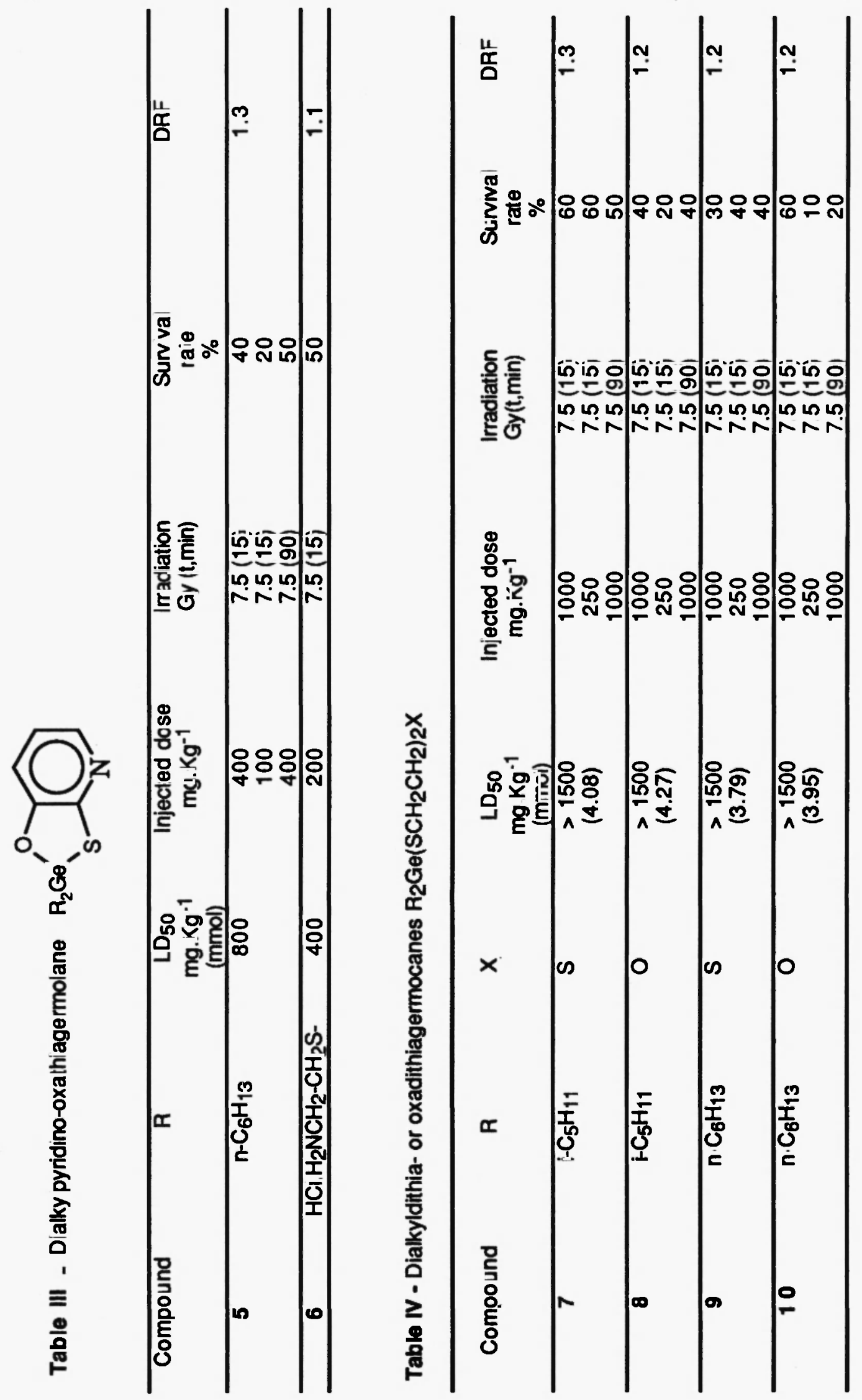


\section{Results and discussion}

\section{Sila- and germathiazolidines}

Silathiazolidine has been prepared by the reaction of the corresponding dichiorosilane with an appropriate $\mathrm{N}$-substituted cysteamine in stoichiometric molar ratio in refluxing anhydrous tetrahydrofuran, Scheme 1 :

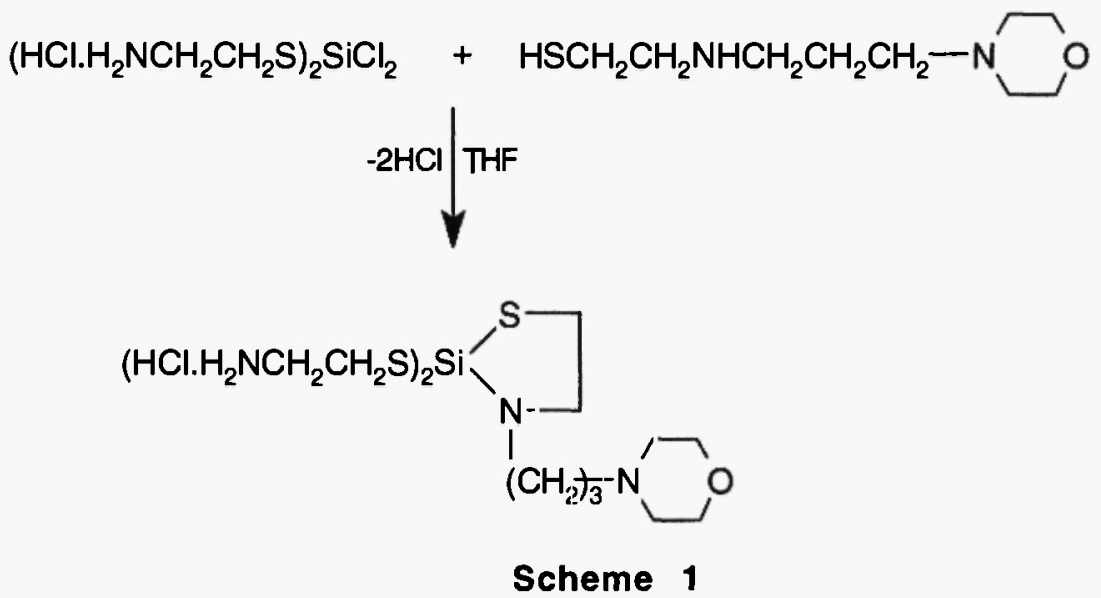

Germathiazolidines have been prepared according to two methods of heterocyclisation already described in the litterature $[1,11,12]$.

\section{Method A}

The action of diorganogermyldichloride [12] (in stoichiometric amounts) on N-substituted cysteamine in refluxing anhydrous THF in the presence of freshly distilled triethylamine gave by a cyclisation reaction, with elimination of hydrochloric acid from $\mathrm{M}-\mathrm{Cl}, \mathrm{SH}$ and $\mathrm{NH}$ [13] groups, the corresponding products, Scheme 2 :

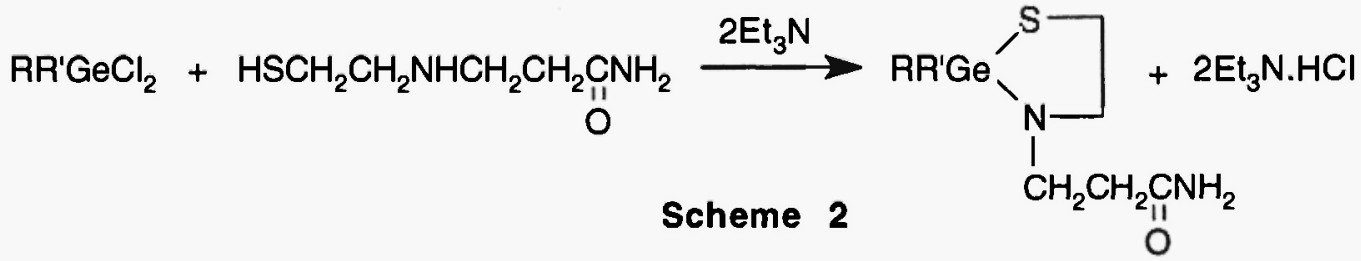

\section{Method B}

Treatment of $\mathrm{N}$-substituted cysteamine, in stoichiometric amounts, with bis(diethylamino) dialkylgermane in anhydrous THF resulted in the cleavage of Ge-N bonds by the N-H and SH groups (a transamination reaction) $[1,12,14]$ forming the corresponding germathiazolidines, Scheme 3 :

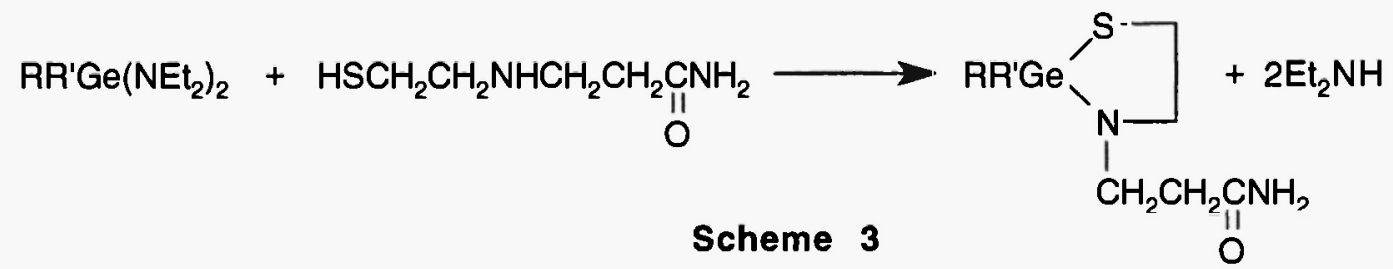

\section{Sila- and germadithioacetals}

Siladithioacetal has been prepared by action of diorganosilyldichloride [4] on $2 \mathrm{~mol}$ of $\mathrm{N}$ substituted cysteamine in refluxing anhydrous tetrahydrofuran, Scheme 4 : 


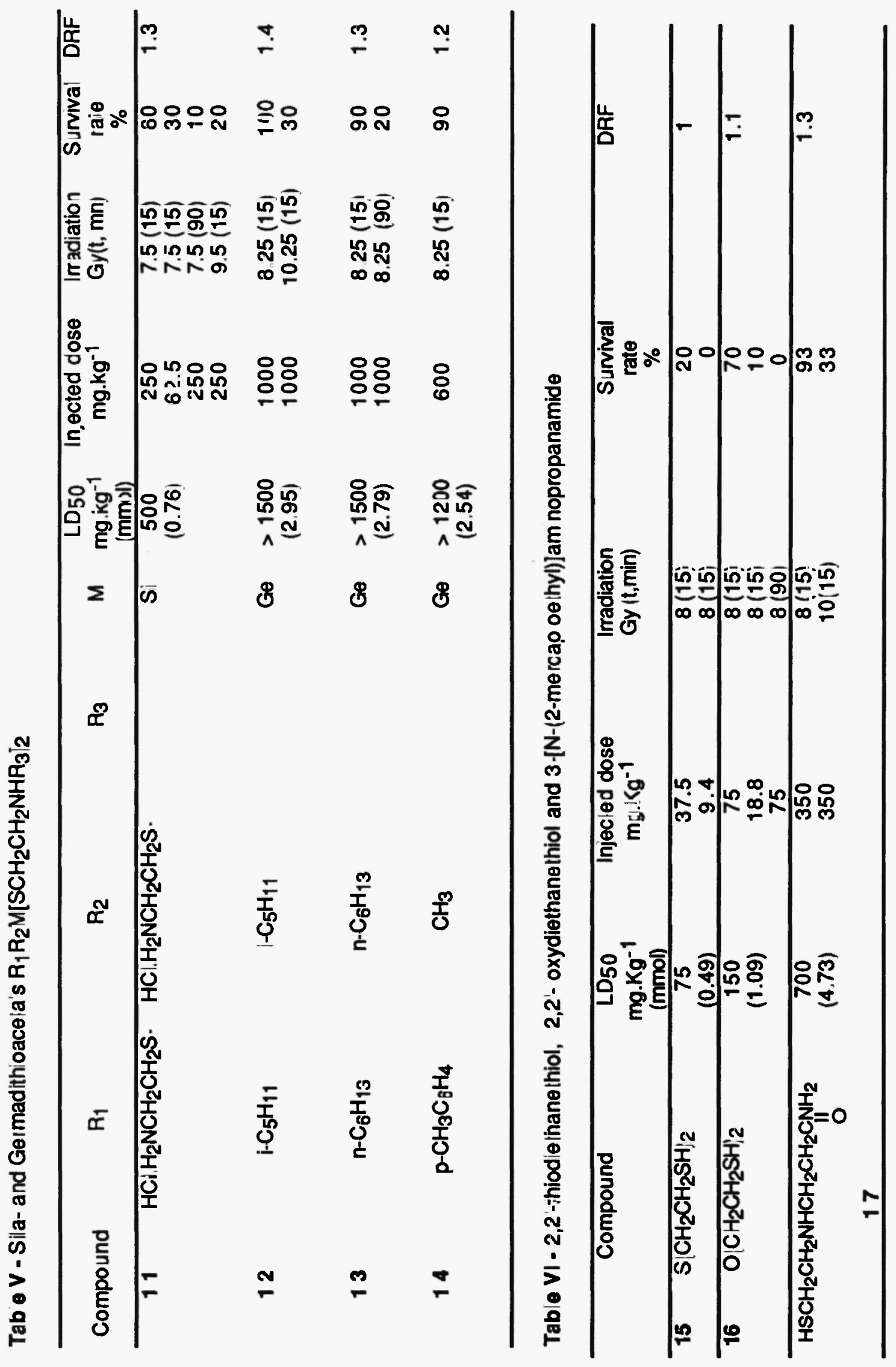




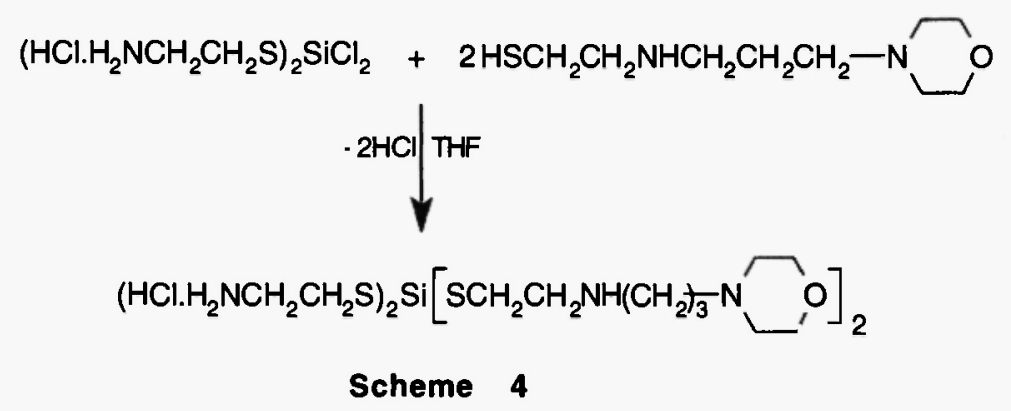

[4].

Germadithioacetals of $\mathrm{N}$-substituted cysteamine were prepared by two method, $\mathrm{C}$ and $\mathrm{D}$

Method C

The reaction of diorganogermyldichloride and $2 \mathrm{~mol}$ of $\mathrm{N}$-substituted cysteamine in the presence of triethylamine in refluxing anhydrous THF lead the acyclic derivatives, Scheme 5 :

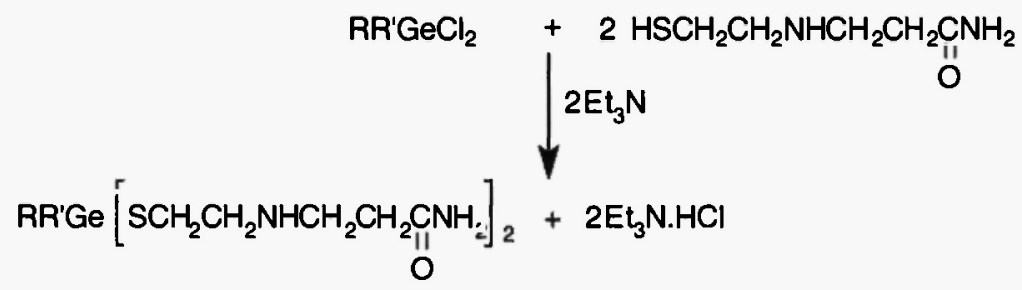

Method D

Scheme 5

The action of $2 \mathrm{~mol}$ of $\mathrm{N}$-substituted cysteamine with bis(diethylamino)dialkylgermane in anhydrous THF (a cleavage reaction of $\mathrm{Ge}-\mathrm{N}$ bonds by the S-H groups) lead to the formation of the desired products, Scheme 6 :

$\mathrm{RR}^{\prime} \mathrm{Ge}\left(\mathrm{NEt}_{2}\right)_{2}+2 \mathrm{HSCH}_{2} \mathrm{CH}_{2} \mathrm{NHCH}_{2} \mathrm{CH}_{2} \mathrm{CNH}_{2} \underset{-2 \mathrm{Et} / \mathrm{NH}}{\longrightarrow} \operatorname{RR} \mathrm{Ne}^{\prime}\left[\mathrm{SCH}_{2} \mathrm{CH}_{2} \mathrm{NHCH}_{2} \mathrm{CH}_{2} \mathrm{CNH}_{2}\right]_{2}$

\section{Scheme 6}

\section{Dialkyloxathiagermolanes}

Reactions of diorganogermyldichloride with 2-mercapto-3-pyridinol in refluxing anhydrous THF in 1:1 molar ratios yield quantitatively oxathiagermolanes derivatives according to the following reactions, Scheme 7 :

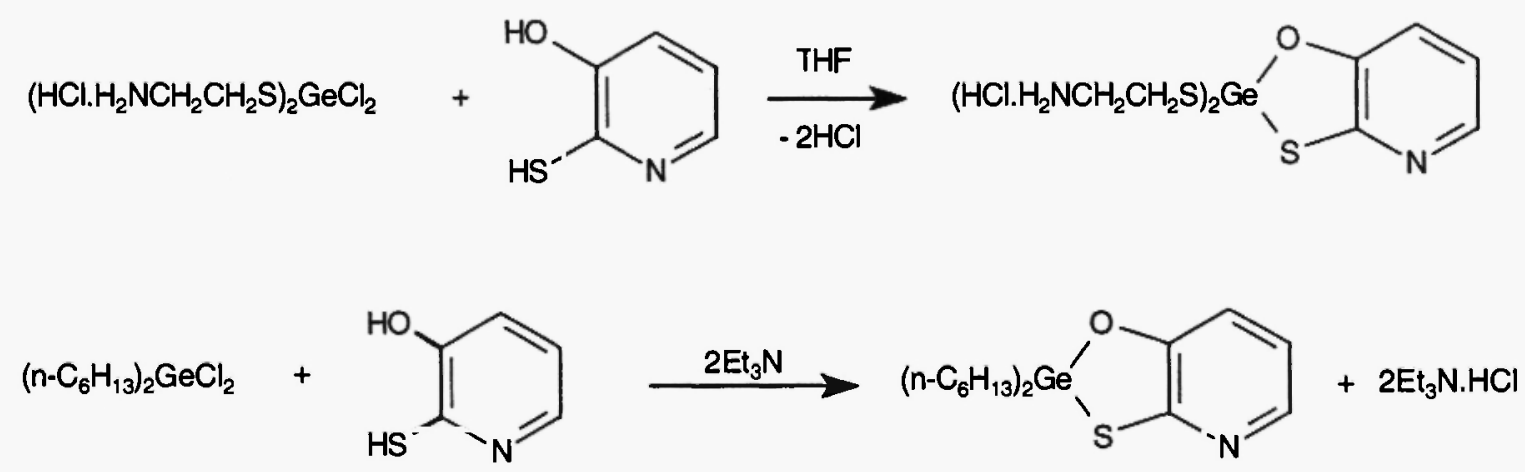


These compounds were obtained by the reaction of 2,2' -thiodiethanethiol or of 2,2' -oxydiethanethiol with dialkylgermyldichloride in equimolar amounts in anhydrous tetrahydrofuran in the presence of freshly distilled triethylamine, Scheme 8 :

$$
\begin{aligned}
& \mathrm{R}_{2} \mathrm{GeCl}_{2}+\left(\mathrm{HSCH}_{2} \mathrm{CH}_{2}\right)_{2} \mathrm{X} \stackrel{2 \mathrm{Et}_{3} \mathrm{~N}}{\longrightarrow} \underset{\mathrm{X}}{\longrightarrow} \mathrm{R}_{2} \mathrm{Ge}\left(\mathrm{SCH}_{2} \mathrm{CH}_{2}\right)_{2} \mathrm{X}+2 \mathrm{Et}_{3} \mathrm{~N} \cdot \mathrm{HCl} \\
&
\end{aligned}
$$

\section{Scheme 8}

\section{Conclusions}

The analysis of the results reported in tables $\|-V$ shows that the organogermylated and organosilylated derivatives described have a radioprotective activity greater than or sometimes equal to that of the starting organic derivatives and always a lower toxicity.

The organosilylated and organogermylated compounds $1,4,7,11,12$ and 13 have an interesting radioprotective activity (DRF between 1.3-1.6) compared with the starting organic compounds for example :

- derivative 1 (DRF = 1.6), LD $50=600 \mathrm{mg} . \mathrm{Kg}^{-1}$ (1.32 mmol, injected) ; derivative 11 (DRF $=1.3), \mathrm{LD}_{50}=500 \mathrm{mg} \cdot \mathrm{Kg}^{-1}(0.76 \mathrm{mmol})$ compared with the starting organic derivative (DRF $\left.=1.2\right)$, $\mathrm{LD}_{50}=450 \mathrm{mg} \cdot \mathrm{Kg}^{-1}(2.20 \mathrm{mmol})[9]$.

- derivative 4 (DRF = 1.4), $L_{50}>1500 \mathrm{mg} \mathrm{Kg}^{-1}(4.62 \mathrm{mmol})$ compared with derivative 17 (DRF = 1.3), $\mathrm{LD}_{50}=700 \mathrm{mg} \cdot \mathrm{Kg}^{-1}(4.73 \mathrm{mmol})$.

- derivative 7 (DRF = 1.3 ), $\mathrm{LD}_{50}>1500 \mathrm{mg} \cdot \mathrm{Kg}^{-1}(4.08 \mathrm{mmol})$ compared with derivative $15 \mathrm{LD}_{50}=75 \mathrm{mg} \cdot \mathrm{Kg}^{-1}(0.49 \mathrm{mmol})$. We observed in this case an important decrease of toxicity with the organogermanium derivative 7 compared with the starting one 15.

Concerning the derivatives 12 and 13 we have noted a lower toxicity compared with the WR-2529 17 and a low increase of radioprotective activity : derivative 12 ( $D R F=1.4$ ) $L_{50}>1500$ $\mathrm{mg} \cdot \mathrm{Kg}^{-1}$ (2.95 mmol) ; derivative 13 (DRF = 1.3) LD50 > $1500 \mathrm{mg} \cdot \mathrm{Kg}^{-1}(2.79 \mathrm{mmol})$; derivative $17 \mathrm{LD}_{50}=700 \mathrm{mg} \cdot \mathrm{Kg}^{-1}(4.73 \mathrm{mmol})$.

With the other organometallic compounds $2,3,5,6,8,9,10$ and 14 we have always observed a low increased activity in chemical radioprotection and a notable decrease of the toxicity compared with unsubstituted organic derivatives.

We have to underline that in all cases the greater radioprotective activity is obtained with organosilylated and organogermylated in spite of lower injected dosages expressed in mmol fractions.

At last, it is important to note the significant radioprotective activity of germa and silathiazolidines, dialkyloxathiagermolanes and dialkylgermocanes when their injection is practized 90 minutes before the irradiation. It confirms the sustained activity found for thiazolidines and indicates that the hydrolysis leading to the cysteamine release is an important mechanism in radioprotection.

In short, the radioprotective activity of organosilylated and organogermylated compounds can be increased compared with unsubstituted organic derivatives by the presence in these molecules of organometallic groups which increase the hydrosolubility and the organic ligands which increase the iiposolubility and globaly the biological activity of these molecules, thereby favoring their passage through the cellular membranes.

The results presented in this paper confirm the positive contribution of germanium and silicon in this field in agreement with previous work [1-9] and the interesting biological activity of organosilicon and organogermanium compounds in different fields [15-22].

\section{Acknowledgements}

The authors wish to thank the Direction des Recherches, Etudes et Techniques, Departement de Chimie-Phamacologie du Ministere de la Defense Nationale, France, for their financial support and interest in this research.

\section{REFERENCES}

1. J. Satgé, A. Cazes, M. Bouchaut, M. Fatome, H. Sentenac-Roumanou and C. Lion, Eur. J. Med.

Chem. 17(1982)433. 
2. M. Fatome, H. Sentenac-Roumanou, C. Lion, J. Satgé, M. Fourtinon and G. Rima, Eur. Med. Chem. 19(1984)119.

3. M. Fatome, H. Sentenac-Roumanou, C. Lion, J. Satgé and G. Rima, Eur. J. Med. Chem. 23(1988)257.

4. J. Satge, G. Rima, M. Fatome, H. Sentenac-Roumanou and C. Lion, Eur. J. Med. Chem. 24(1989)48.

5. G. Rima, J. Satge, C. Lion, H. Sentenac-Roumanou and D. Guyot, Synth. React. Inorg. Met.-Org. Chem. 19(1989)787.

6. G. Rima, J. Satgé, M. Fatome, J.D. Laval, H. Sentenac-Roumanou, C. Lion and M. Lazraq, Eur. J. Med. Chem. 26(1991)291.

7. G. Rima, J. Satgé, H. Sentenac-Roumanou, M. Fatome, C. Lion and J.D. Laval, Eur. J. Med. Chem. 28(1993)761.

8. G. Rima, J. Satgé, H. Sentenac-Roumanou, M. Fatome, J.D. Laval, C. Lion, O. Alazard and P. Chabertier, Appl. Organomet. Chem. 8(1994)481.

9. G. Rima, J. Satgé, H. Sentenac-Roumanou, M. Fatome, J. D. Laval, C. Lion and R. Dagiral, Appl. Organomet. Chem. 10(1996)113.

10. F. I. Carroll, H. M. Dickson and M. E. Wall, J. Org. Chem. 30(1965)33.

11. G. Dousse, J. Satgé, M. Riviere-Baudet, Synth. React. Inorg. Met.-Org. Chem. 3(1973)11.

12. M. Lesbre, P. Mazerolles and J. Satgé in : The Organic Compounds of Germanium, John Wiley and Sons, New York, (1973)

13. J. Satge, M. Lesbre and M. Baudet, C.R. Acad. Sci. Paris, Ser. C. 259(1964)4733.

14. J. Satgé and M. Baudet, C.R. Acad. Sci. Paris Ser. C. 263(1966)435.

15. G. Atassi, Rev. Silicon Germanium Tin Lead Compd., 8(1985)219.

16. J. S. Thayer, Rev. Silicon Germanium Tin Lead Compd., 8(1985)133; Appl. Organomet. Chem., 1(1987)227.

17. T. K. Gar and V. F. Mironov, in : Review of the Biological Activity of Germanium Compounds, Niitekhim, (1982), Moscow

18. E. Lukevics and L. Ignatovich, Appl. Organomet. Chem., 6(1992)113.

19. E. Lukevics and L. Ignatovich, N. Shilena and S. Germane, Appl. Organomet . Chem., 6(1992)261.

20. E. Lukevics, S. Germane and L. Ignatovich, Appl. Organomet. Chem., 6(1992)543.

21. F. Anger, J. P. Anger, L. Guillou and A. Papillon, Appl. Organomet. Chem., 6(1992)267.

22. R. Tacke, D. Reichel, P. G. Jones, X. Hou, M. Waelbroeck, J. Gross, E. Mutschler and G. Lambrecht, J. Organomet. Chem., 521(1996)305.

Received: December 17, 1996 - Accepted: January 17, 1997 Accepted in revised camera-ready format: January 27, 1997 
